\title{
A simple, rapid, and reliable protocol to localize hydrogen peroxide in large plant organs by DAB-mediated tissue printing
}

\author{
Yong-Hua Liu ${ }^{1,2}$, Christina E. Offler ${ }^{1}$ and Yong-Ling Ruan ${ }^{1}$ * \\ 'Australia-China Research Centre for Crop Improvement and School of Environmental and Life Sciences, The University of Newcastle, Callaghan, NSW, \\ Australia \\ 2 Institute of Vegetables, Zhejiang Academy of Agricultural Sciences, Hangzhou, China
}

\author{
Edited by: \\ Jirong Huang, University of Tokyo, \\ Japan \\ Reviewed by: \\ Vasileios Fotopoulos, Cyprus \\ University of Technology, Cyprus \\ Han Xiao, Shanghai Institutes for \\ Biological Sciences - Chinese \\ Academy of Sciences, China \\ *Correspondence: \\ Yong-Ling Ruan, Australia-China \\ Research Centre for Crop \\ Improvement and School of \\ Environmental and Life Sciences, The \\ University of Newcastle, Callaghan, \\ NSW 2308, Australia \\ e-mail: yong-ling.ruan@newcastle. \\ edu.au
}

Hydrogen peroxide $\left(\mathrm{H}_{2} \mathrm{O}_{2}\right)$ is a major reactive oxygen species (ROS) and plays diverse roles in plant development and stress responses. However, its localization in large and thick plant organs (e.g., stem, roots, and fruits), other than leaves, has proven to be challenging due to the difficulties for the commonly used $\mathrm{H}_{2} \mathrm{O}_{2}$-specific chemicals, such as 3,3'-diaminobenzidine (DAB), cerium chloride $\left(\mathrm{CeCl}_{3}\right)$, and $2^{\prime}, 7^{\prime}$-dichlorofluorescin diacetate $\left(\mathrm{H}_{2}\right.$ DCF-DA), to penetrate those organs. Theoretically, the reaction of endogenous $\mathrm{H}_{2} \mathrm{O}_{2}$ with these chemicals could be facilitated by using thin organ sections. However, the rapid production of wound-induced $\mathrm{H}_{2} \mathrm{O}_{2}$ associated with this procedure inevitably disturbs the original distribution of $\mathrm{H}_{2} \mathrm{O}_{2}$ in vivo. Here, by employing tomato seedling stems and fruits as testing materials, we report a novel, simple, and rapid protocol to localize $\mathrm{H}_{2} \mathrm{O}_{2}$ in those organs using DAB-mediated tissue printing. The rapidity of the protocol (within $15 \mathrm{~s})$ completely avoided the interference of wound-induced $\mathrm{H}_{2} \mathrm{O}_{2}$ during experimentation. Moreover, the $\mathrm{H}_{2} \mathrm{O}_{2}$ signal on the printing was stable for at least $1 \mathrm{~h}$ with no or little background produced. We conclude that DAB-mediated tissue printing developed here provide a new feasible and reliable method to localize $\mathrm{H}_{2} \mathrm{O}_{2}$ in large plant organs, hence should have broad applications in studying ROS biology.

Keywords: fruits and stems, hydrogen peroxide, localization, tissue printing, reactive oxygen species

\section{INTRODUCTION}

Reactive oxygen species (ROS) accumulate when plants are under various biotic (pathogen attack) and abiotic (e.g., high light, drought, heat, salt, and heavy metal) stresses (Apel and Hirt, 2004; Suzuki et al., 2012; Choudhury et al., 2013). On one hand, excessive ROS cause oxidative damage to proteins, DNA, and lipids. On the other hand, ROS also act as signaling molecules to regulate development and stress responses (Apel and Hirt, 2004). There are different kinds of ROS in plants, including singlet oxygen $\left({ }^{1} \mathrm{O}_{2}\right)$, superoxide $\left(\mathrm{O}_{2}^{-}\right), \mathrm{H}_{2} \mathrm{O}_{2}$, and hydroxyl radical $\left(\mathrm{OH}^{-}\right)$. Among them, $\mathrm{H}_{2} \mathrm{O}_{2}$ is thought to be relatively stable (Bienert et al., 2007) and the most likely signaling ROS to regulate developmental and stress responses (Van Breusegem et al., 2008), and thus one of the most studied ROS species.

Hydrogen peroxide could be detected quantitatively and qualitatively. Accurate quantification of $\mathrm{H}_{2} \mathrm{O}_{2}$ in plant organs, however, is difficult to achieve owing to the unique properties of $\mathrm{H}_{2} \mathrm{O}_{2}$ being highly metabolically active with a half-life of only $1 \mathrm{~ms}$ in plants (Reth, 2002; Veljovic-Jovanovic et al., 2002; Petrov and Van Breusegem, 2012). Even storage of plant materials at $-80^{\circ} \mathrm{C}$ may result in the loss of $\mathrm{H}_{2} \mathrm{O}_{2}$ by as much as $60 \%$ within 7 days (Cheeseman, 2006). Moreover, $\mathrm{H}_{2} \mathrm{O}_{2}$ may react with many reduced

Abbreviations: DAB, 3,3'-diaminobenzidine; DAF, days after flowering; $\mathrm{H}_{2} \mathrm{DCF}$ DA, $2^{\prime}, 7^{\prime}$-dichlorofluorescin diacetate; ROS, reactive oxygen species; TEM, transmission electron microscopy. compounds released during homogenization of plant materials, such as ascorbic acid which leads to underestimation of $\mathrm{H}_{2} \mathrm{O}_{2}$ levels. The level of $\mathrm{H}_{2} \mathrm{O}_{2}$ could also be overestimated because of endogenous phenolics in plant tissues (Veljovic-Jovanovic et al., 2002). In fact, it has been reported that $\mathrm{H}_{2} \mathrm{O}_{2}$ content can span more than several orders of magnitude even for leaves from the same species (from nM to mM; Cheeseman, 2006; Razem, 2008), indicating major challenges in $\mathrm{H}_{2} \mathrm{O}_{2}$ quantification.

Hydrogen peroxide can also be qualitatively localized at a tissue or cellular level. Compared to the measurement of $\mathrm{H}_{2} \mathrm{O}_{2}$ extracted from whole plant organs, this approach has the advantage of localizing $\mathrm{H}_{2} \mathrm{O}_{2}$ in particular cellular sites in a multicellular tissue or organ, thereby potentially providing deep insights into the cellular origin and function of the $\mathrm{H}_{2} \mathrm{O}_{2}$. Localization of $\mathrm{H}_{2} \mathrm{O}_{2}$ relies on histochemical staining of plant organs. The most commonly used chemicals to localize $\mathrm{H}_{2} \mathrm{O}_{2}$ in planta are 3,3'-diaminobenzidine (DAB), cerium chloride $\left(\mathrm{CeCl}_{3}\right)$, and $2^{\prime}, 7^{\prime}$-dichlorofluorescin diacetate $\left(\mathrm{H}_{2}\right.$ DCF-DA). However, detection of $\mathrm{H}_{2} \mathrm{O}_{2}$ with $\mathrm{DAB}$ requires a long incubation time with $\mathrm{DAB}$ solution. For example, $\mathrm{H}_{2} \mathrm{O}_{2}$ localization in detached leaves and tender seedling roots usually needs more than $8 \mathrm{~h}$ incubation in DAB solution (Thordal-Christensen etal., 1997; Salzer etal., 1999). To gain higher resolution of the cellular localization of $\mathrm{H}_{2} \mathrm{O}_{2}$, a TEM method has also been employed. In this method, endogenous $\mathrm{H}_{2} \mathrm{O}_{2}$ reacts with exogenously supplied $\mathrm{CeCl}_{3}$ to form cerium perhydroxide, which gives dark deposits under TEM. However, before 
samples are fixed for TEM, leaves must be incubated in $\mathrm{CeCl}_{3}$ solution for at least $1 \mathrm{~h}$ to allow the penetration of $\mathrm{CeCl}_{3}$ into the tissue and the formation of cerium perhydroxide (Bestwick et al., 1997; Romero-Puertas et al., 2004). Such a long period of incubation of detached plant organs in $\mathrm{DAB}$ and $\mathrm{CeCl}_{3}$ solution would inevitably change the distribution pattern of $\mathrm{H}_{2} \mathrm{O}_{2}$ in vivo, because of both the rapid degradation of original $\mathrm{H}_{2} \mathrm{O}_{2}$ due to its short half-life and the de novo production of wound-induced $\mathrm{H}_{2} \mathrm{O}_{2}$. Queval et al. (2008) has suggested that DAB staining only reflect the production of $\mathrm{H}_{2} \mathrm{O}_{2}$ rather than its original concentration or distribution. Indeed, it has been reported that $\mathrm{H}_{2} \mathrm{O}_{2}$ accumulates rapidly at the cutting site of Arabidopsis stem, within 1 min after cutting, and furthermore the wound-induced $\mathrm{H}_{2} \mathrm{O}_{2}$ signal can travel at a speed of $8.4 \mathrm{~cm} \mathrm{~min}^{-1}$ and induce dramatic increase of $\mathrm{H}_{2} \mathrm{O}_{2}$ in distal cotyledons within 2 min (Miller et al., 2009).

Although $\mathrm{H}_{2}$ DCF-DA staining takes a shorter incubation time (10 min) than $\mathrm{DAB}$ and $\mathrm{CeCl}_{3}$ staining, it is mostly used for the visualization of $\mathrm{H}_{2} \mathrm{O}_{2}$ on the surface of plant organs such as, epidermis of citrus fruit (Macarisin et al., 2007) and tobacco leaves (Essmann etal., 2008). To the best of our knowledge, there have been no reports on using the above-mentioned three chemicals to localize $\mathrm{H}_{2} \mathrm{O}_{2}$ in the inner parts of large plant organs (e.g., stem and fruit). The most likely reason for this scenario is the difficulties for these chemicals to infiltrate into the large plant organs. This was indeed the case in our preliminary studies on tomato ovaries using DAB and $\mathrm{H}_{2}$ DCF-DA staining. Only recently, $\mathrm{H}_{2} \mathrm{O}_{2}$ localization in seed has been reported in a study on rice using $\mathrm{H}_{2}$ DCF-DA (Nagasawa et al., 2013), in which seeds were sectioned in half before staining. Although sectioning facilitated the reaction of $\mathrm{H}_{2}$ DCF-DA with $\mathrm{H}_{2} \mathrm{O}_{2}$, the rapid production of wound-induced $\mathrm{H}_{2} \mathrm{O}_{2}$ could dramatically alter the original distribution of $\mathrm{H}_{2} \mathrm{O}_{2}$ and yield an artifact of overestimate of $\mathrm{H}_{2} \mathrm{O}_{2}$ level, just as discussed above. Thus, how to avoid or minimize the interference of wound-induced $\mathrm{H}_{2} \mathrm{O}_{2}$ is a prerequisite for the accurate localization of $\mathrm{H}_{2} \mathrm{O}_{2}$ in organ sections.

Some studies have endeavored to tackle the problem of woundinduced production of $\mathrm{H}_{2} \mathrm{O}_{2}$. For example, starch/KI-mediated tissue printing has been used to localize $\mathrm{H}_{2} \mathrm{O}_{2}$ in the stem of seedlings from different plant species including soybean, pea, common bean, sunflower, and cucumber (Schopfer, 1994). In this procedure, the sections of seedling stem were pressed for $60 \mathrm{~s}$, immediately after cutting, on nitrocellulose paper impregnated with starch/KI solution. The oxidation of $\mathrm{KI}_{\text {to }} \mathrm{I}_{2}$ by $\mathrm{H}_{2} \mathrm{O}_{2}$ can produce the blue-black $\mathrm{I}_{2}$-starch complex (Olson and Varner, 1993), which can be photographed under the microscope. The whole procedure can be completed in just $70 \mathrm{~s}$, and thus wound-induced $\mathrm{H}_{2} \mathrm{O}_{2}$ can be avoided to a large extent (Schopfer, 1994). However, the intensity of color increases with time after printing, and therefore the signal must be observed and recorded immediately (Schopfer, 1994). In addition, there is a background color due to continuous autoxidation of KI, which interferes and blurs the results (Neves et al., 1998; Przymusiński et al., 2007).

After being absorbed into plant cells, DAB reacts with $\mathrm{H}_{2} \mathrm{O}_{2}$ to form a reddish-brown polymer in the presence of peroxidase (Thordal-Christensen et al., 1997). DAB-mediated tissue printing has been employed to localize peroxidase in plants (Spruce et al.,
1987). However, there has been no report on DAB-mediated tissue printing to directly localize $\mathrm{H}_{2} \mathrm{O}_{2}$ in plants. Here, we described such a novel procedure. The new protocol can rapidly and reliably localize $\mathrm{H}_{2} \mathrm{O}_{2}$ in sections of large tomato organs, namely stems and fruits. The whole procedure was completed within $15 \mathrm{~s}$ which avoided the interference of wound-induced $\mathrm{H}_{2} \mathrm{O}_{2}$. At the same time, the signal was very stable for at least $1 \mathrm{~h}$ with little background produced.

\section{MATERIALS AND METHODS $\mathrm{H}_{2} \mathrm{O}_{2}$ LOCALIZATION BY DAB-MEDIATED TISSUE PRINTING}

Nitrocellulose membrane $\left(0.45 \mu \mathrm{m}\right.$ in pore size, Hybond ${ }^{\mathrm{TM}}-\mathrm{C}$ Extra, Amersham) was soaked in $5 \mathrm{mg} \mathrm{mL}^{-1} \mathrm{DAB}-\mathrm{HCl}$ solution $(\mathrm{pH}$ 3.8) and then air-dried at room temperature for $30 \mathrm{~min}$ in the dark. The soaked nitrocellulose membrane was placed on a layer of un-soaked nitrocellulose membrane, which can absorb excessive plant exudate from cutting site during tissue printing. Tissue printing was performed at $\sim 20^{\circ} \mathrm{C}$. Free-hand sections in $1.0 \mathrm{~mm}$ thickness were prepared with a razor blade. The sections were cut from the top, middle, and bottom positions of stems of 50-days old seedlings, or transversely from the middle of fruits at 5 and 10 DAF. The sections were gently pressed onto the impregnated nitrocellulose membrane with forefinger for $10 \mathrm{~s}$ to ensure that $\mathrm{H}_{2} \mathrm{O}_{2}$ in sections is successfully transferred to membrane and at the same time the sections are not crushed by the press. Then, the sections were carefully removed with forceps. This, together with the $5 \mathrm{~s}$ required for the cutting of the section, renders the total time for tissue printing being only $15 \mathrm{~s}$. The membrane was then washed in $100 \%$ ethanol to remove the possible interfering substance (e.g., chlorophyll) and photographed under a dissection microscope after $5 \mathrm{~min}$ at room temperature to allow completion of the reaction between the $\mathrm{H}_{2} \mathrm{O}_{2}$ derived from plant cells and DAB pre-soaked in the membrane.

To verify the specificity of reaction, tissue printings were also done as above on membranes pre-soaked in $5 \mathrm{mg} \mathrm{mL}^{-1} \mathrm{DAB}-$ $\mathrm{HCl}$ solution ( $\mathrm{pH} 3.8$ ) containing $100 \mathrm{mM}$ ascorbic acid. To test whether there is a production of wound-induced $\mathrm{H}_{2} \mathrm{O}_{2}$ under our experimental conditions, tissue printing was performed at 0,1 , and 2 min after sectioning. To test if endogenous peroxidase was sufficient to support the reaction, $\mathrm{H}_{2} \mathrm{O}_{2}$ was introduced exogenously by soaking nitrocellulose membrane in $5 \mathrm{mg} \mathrm{mL}^{-1} \mathrm{DAB}-\mathrm{HCl}$ solution (pH 3.8) containing $20 \mathrm{mM} \mathrm{H}_{2} \mathrm{O}_{2}$ and tissue printing was done as described above. If the endogenous peroxidase is sufficient, it can be expected that the tissue printing with exogenously supplied $\mathrm{H}_{2} \mathrm{O}_{2}$ would produce stronger signals.

\section{$\mathrm{H}_{2} \mathrm{O}_{2}$ QUANTIFICATION IN TOMATO STEMS}

Hydrogen peroxide extraction was carried out according to Veljovic-Jovanovic et al. (2002). Briefly, $100 \mathrm{mg}$ of stem from the top, middle, and bottom part of tomato seedlings was harvested, snap-frozen in liquid nitrogen and analyzed immediately. Samples were homogenized in $1.5 \mathrm{~mL} 1 \mathrm{M} \mathrm{HClO}_{4}$ with $100 \mathrm{mg}$ of insoluble polyvinylpyrrolidone, which can remove phenolic compounds. Homogenates were centrifuged at $13000 \times g$ for 10 min at $4^{\circ} \mathrm{C}$. The $\mathrm{H}_{2} \mathrm{O}_{2}$ content in the supernatant was then determined as described by Cheeseman (2006). Briefly, $60 \mu \mathrm{L}$ 
extract was mixed with $600 \mu \mathrm{L}$ eFOX reagents (containing $250 \mu \mathrm{M}$ ferrous ammonium sulfate, $100 \mu \mathrm{M}$ sorbitol, $100 \mu \mathrm{M}$ xylenol orange, and $1 \%$ ethanol in $25 \mathrm{mM} \mathrm{H}_{2} \mathrm{SO}_{4}$ ). Then, the difference in absorbance between 550 and $800 \mathrm{~nm}$ was recorded at least 30 min after mixing the supernatant with the eFOX reagents. The content of $\mathrm{H}_{2} \mathrm{O}_{2}$ was calculated using a standard curve of $\mathrm{H}_{2} \mathrm{O}_{2}$.

\section{STATISTICAL ANALYSIS}

One-way ANOVA was done using IBM SPSS Statistics 20.

\section{RESULTS AND DISCUSSION \\ THE DAB-MEDIATED TISSUE PRINTING FOR LOCALIZING $\mathrm{H}_{2} \mathrm{O}_{2}$ IS SIMPLE, RAPID, AND RELIABLE}

Unless otherwise specified, tissue printing of tomato stem was always conducted on sections from the middle part of the seedling. We found that tissue printing of stem sections on nitrocellulose membrane for $10 \mathrm{~s}$ produced significant reddish-brown color at the cortex and vascular bundle regions (Figures 1A,B). To verify if the color is $\mathrm{H}_{2} \mathrm{O}_{2}$-specific, the reaction was done in the presence of ascorbic acid, a specific $\mathrm{H}_{2} \mathrm{O}_{2}$ scavenger (Thordal-Christensen et al., 1997). Since the nitrocellulose membrane needed to be airdried for $30 \mathrm{~min}$ before it being used for tissue printing, it is possible that the soaked ascorbic acid might be oxidized. Therefore, to ensure there was sufficient reduced form ascorbic acid
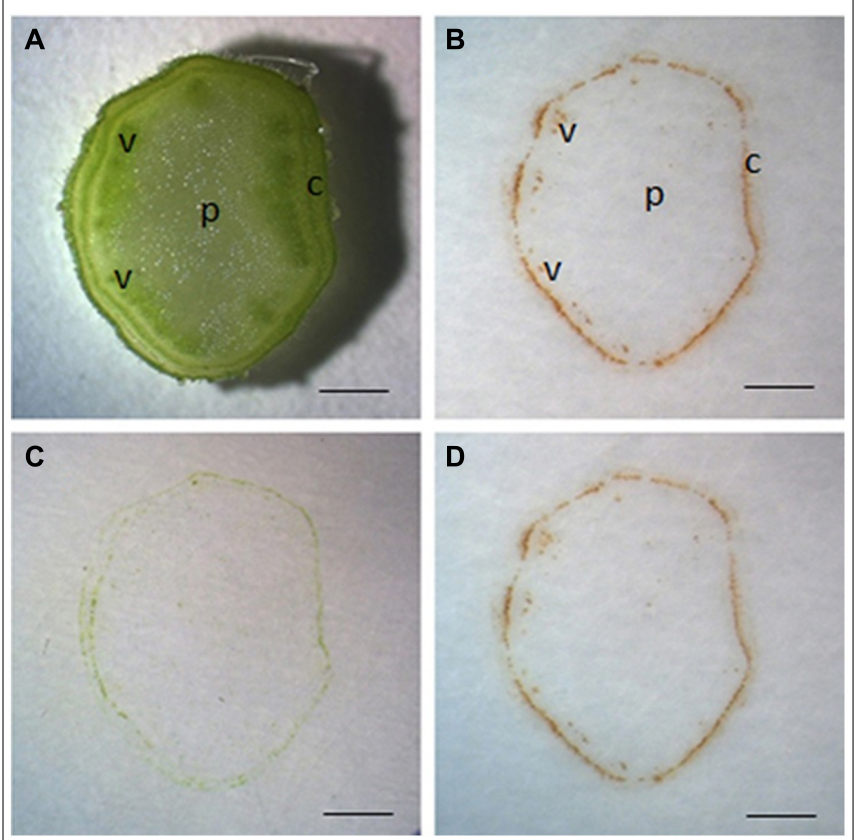

FIGURE 1 | Localization of $\mathrm{H}_{2} \mathrm{O}_{2}$ by DAB-mediated tissue printing in stems of tomato seedlings. Free-hand sections (1 mm thick) were cut from the middle of tomato stem for tissue printing (A). The sections were pressed for $10 \mathrm{~s}$ on nitrocellulose membrane impregnated in $5 \mathrm{mg} \mathrm{mL}^{-1}$ DAB-HCl solution ( $\mathrm{pH} 3.8$ ) and photographed immediately (B) or $1 \mathrm{~h}$ later (D). To verify the specificity of reaction, the sections were also pressed to membrane impregnated in $5 \mathrm{mg} \mathrm{mL}^{-1} \mathrm{DAB}-\mathrm{HCl}$ solution ( $\mathrm{pH}$.8) plus $100 \mathrm{mM}$ ascorbic acid (C). Sections used in this figure were consecutive sections from the same stem. c, cortex; $p$, pith; v, vascular bundle. Scale bar $=1 \mathrm{~mm}$ in (A-D). in membrane for the specific reaction with $\mathrm{H}_{2} \mathrm{O}_{2}$, we employed higher concentration of ascorbic acid (100 mM) than the commonly used concentration (10 mM; Thordal-Christensen et al., 1997; Salzer et al., 1999). It was found that no color was produced under ascorbic acid treatment (Figure 1C), indicating that the reaction was $\mathrm{H}_{2} \mathrm{O}_{2}$-specific. The same printing in Figure 1A was photographed again $1 \mathrm{~h}$ later with no significant changes in the $\mathrm{H}_{2} \mathrm{O}_{2}$ signal strength (Figure 1D). Furthermore, no obvious background color was developed following $1 \mathrm{~h}$ at room temperature (Figure 1D). Therefore, it can be concluded that our protocol to localize $\mathrm{H}_{2} \mathrm{O}_{2}$ in stem with DAB-mediated tissue printing is simple, rapid, and reliable.

\section{WOUND-INDUCED $\mathrm{H}_{\mathbf{2}} \mathrm{O}_{\mathbf{2}}$ IS AVOIDED IN THE REACTION}

Previous studies have shown that $\mathrm{H}_{2} \mathrm{O}_{2}$ can be rapidly induced by wounding (Olson and Varner, 1993; Miller et al., 2009). To test the possible involvement of wound-induced $\mathrm{H}_{2} \mathrm{O}_{2}$ in the current protocol, tissue printing was performed at 0,1 , and 2 min after sectioning using consecutive sections. It was found there was no difference in $\mathrm{H}_{2} \mathrm{O}_{2}$ distribution between 0 and 1 min after sectioning, and $\mathrm{H}_{2} \mathrm{O}_{2}$ was mainly confined in the cortex and vascular
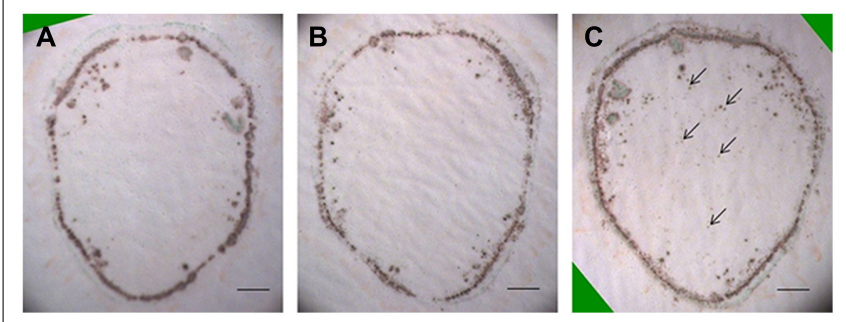

FIGURE 2 | Accumulation of wound-induced $\mathrm{H}_{2} \mathrm{O}_{2}$ in tomato stem after sectioning. Free-hand sections (1 $\mathrm{mm}$ thick) were cut from the middle of tomato stem for tissue printing at 0 (A), 1 (B), and 2 (C) min after cutting. In (A,B), no difference was found in $\mathrm{H}_{2} \mathrm{O}_{2}$ distribution pattern. In (C), however, $\mathrm{H}_{2} \mathrm{O}_{2}$ was found in pith area (arrows) where no $\mathrm{H}_{2} \mathrm{O}_{2}$ was detected in (A, $\mathbf{B})$, indicating the accumulation of wound-induced $\mathrm{H}_{2} \mathrm{O}_{2}$ at $2 \mathrm{~min}$ after cutting. Sections used in this figure were consecutive sections from the same stem. Scale bar $=1 \mathrm{~mm}$ in $\mathbf{( A - C )}$.
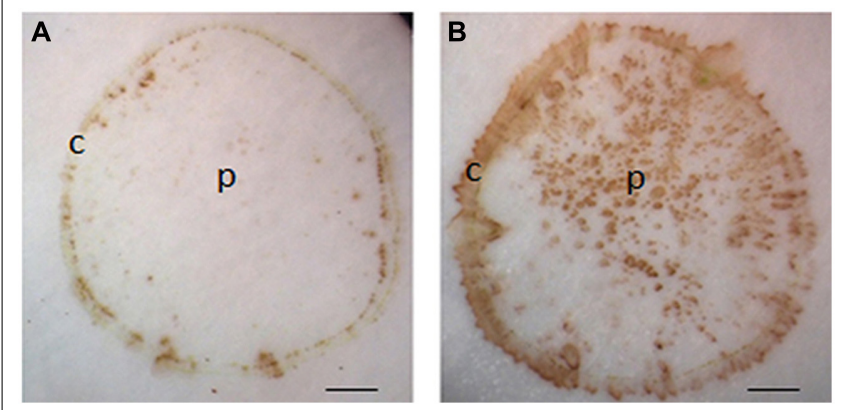

FIGURE 3 | Effects of exogenously applied $\mathrm{H}_{2} \mathrm{O}_{2}$ on $\mathrm{H}_{2} \mathrm{O}_{2}$ signal strength in tomato seedling stems. Tissue printing was conducted on nitrocellulose membranes without (A) and with (B) exogenously supplied $20 \mathrm{mM} \mathrm{H} \mathrm{O}_{2}$. Note, application of exogenously supplied $\mathrm{H}_{2} \mathrm{O}_{2}$ increased the intensity of signals in the cortex, and with additional signals apparently detected in the pith region of tomato stem in (B) as compared to that in (A). c, cortex; p, pith; Scale bar $=1 \mathrm{~mm}$ in $(\mathbf{A}, \mathbf{B})$. 

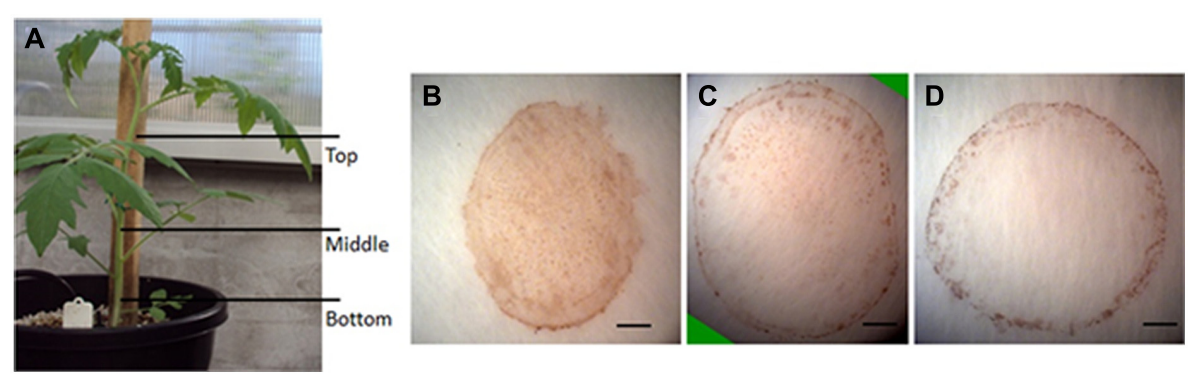

FIGURE 4 | Localization of $\mathbf{H}_{\mathbf{2}} \mathbf{O}_{\mathbf{2}}$ in different parts of tomato seedling stems. Stem sections were cut from different positions as indicated in (A) for $\mathrm{H}_{2} \mathrm{O}_{2}$ localization at the top (B), middle (C), and bottom (D) of tomato stems using DAB-mediated tissue printing. Scale bars in (B-D) represent 1, 1.2, and 1 mm, respectively.

bundles with no signal found in the pith (Figures 2A,B). However, obvious $\mathrm{H}_{2} \mathrm{O}_{2}$ signal was produced in the pith when tissue printing was conducted 2 min after sectioning (Figure 2C), indicating the production of wound-induced $\mathrm{H}_{2} \mathrm{O}_{2}$. These results indicate that although wound-induced $\mathrm{H}_{2} \mathrm{O}_{2}$ accumulated very quickly (within 2 min after cutting), the rapidity of our protocol (within $15 \mathrm{~s}$, see Materials and Methods for details) can completely avoid the interference of wound-induced $\mathrm{H}_{2} \mathrm{O}_{2}$.

\section{ENDOGENOUS PEROXIDASE IS SUFFICIENT TO SUPPORT THE REACTION}

The reaction between $\mathrm{DAB}$ and $\mathrm{H}_{2} \mathrm{O}_{2}$ relies on the activity of peroxidase (Thordal-Christensen et al., 1997). In our protocol, $\mathrm{H}_{2} \mathrm{O}_{2}$ was localized using exogenous DAB and endogenous peroxidase. Undoubtedly, the exogenously supplied DAB used in our protocol was sufficient to support the reaction (Spruce et al., 1987; Thordal-Christensen et al., 1997). However, it is unknown whether endogenous peroxidase activity is enough for the reaction. To address this issue, exogenous $\mathrm{H}_{2} \mathrm{O}_{2}$ was introduced by soaking nitrocellulose in DAB solution containing $20 \mathrm{mM}$ $\mathrm{H}_{2} \mathrm{O}_{2}$. If the activity of endogenous peroxidase from the stem section is more than enough for the reaction, the color intensity for $\mathrm{H}_{2} \mathrm{O}_{2}$ on tissue printing should become stronger in the presence of exogenously supplied $\mathrm{H}_{2} \mathrm{O}_{2}$. As expected, $\mathrm{H}_{2} \mathrm{O}_{2}$ was found in the cortex but not in the pith in the absence of exogenously supplied $\mathrm{H}_{2} \mathrm{O}_{2}$ (Figure 3A). However, $\mathrm{H}_{2} \mathrm{O}_{2}$ signal strength increased not only in the cortex but also appeared in the pith when the nitrocellulose membrane was pre-soaked with exogenous $\mathrm{H}_{2} \mathrm{O}_{2}$ (Figure 3B). These observations indicate that the activity of endogenous peroxidase was sufficient to support the reaction between endogenous $\mathrm{H}_{2} \mathrm{O}_{2}$ and exogenously supplied DAB.

\section{$\mathrm{H}_{2} \mathrm{O}_{2}$ DISTRIBUTION CHANGES DEVELOPMENTALLY IN TOMATO STEMS AND FRUITS}

The production of $\mathrm{H}_{2} \mathrm{O}_{2}$ is tightly regulated during plant development. For example, using starch/KI-mediated tissue printing, Schopfer (1994) showed that $\mathrm{H}_{2} \mathrm{O}_{2}$ level dramatically increases from the hook region toward the root in 5 days old soybean seedlings. Using the current protocol, we studied $\mathrm{H}_{2} \mathrm{O}_{2}$ distribution along the stem of tomato seedlings (Figure $4 \mathrm{~A}$ ). The analyzes revealed that the distribution patterns of $\mathrm{H}_{2} \mathrm{O}_{2}$ were strikingly different among the top, middle, and bottom regions of tomato seedling. $\mathrm{H}_{2} \mathrm{O}_{2}$ was distributed throughout the whole section at the top of seedlings (Figure 4B). However, the signal strength of $\mathrm{H}_{2} \mathrm{O}_{2}$ in pith decreased at the middle and bottom regions of the stem (Figures 4C,D), with $\mathrm{H}_{2} \mathrm{O}_{2}$ detected only in the cortex at the bottom area of the stem (Figure 4D). Accompanying the changed distribution pattern, $\mathrm{H}_{2} \mathrm{O}_{2}$ content appeared to decrease along stems from the top to the bottom. This observation on $\mathrm{H}_{2} \mathrm{O}_{2}$ gradient along tomato stems is contrary to that reported in soybean (Schopfer, 1994). The reason for the discrepancy may lie in different cultivation conditions. The soybean seedlings were grown in darkness (Schopfer, 1994), whereas our tomato seedlings were grown under normal conditions $(10 / 14 \mathrm{~h}$, day/night). To verify the reliability of our observation, $\mathrm{H}_{2} \mathrm{O}_{2}$ concentration was measured in tissue extracts at the top, middle, and bottom of tomato seedling stems. It was found that $\mathrm{H}_{2} \mathrm{O}_{2}$ content indeed decreased down the stem. $\mathrm{H}_{2} \mathrm{O}_{2}$ content at the top of seedling stem was one and two times higher than that at the middle and bottom part, respectively (Figure 5). The consistency between the quantified value (Figure 5) and

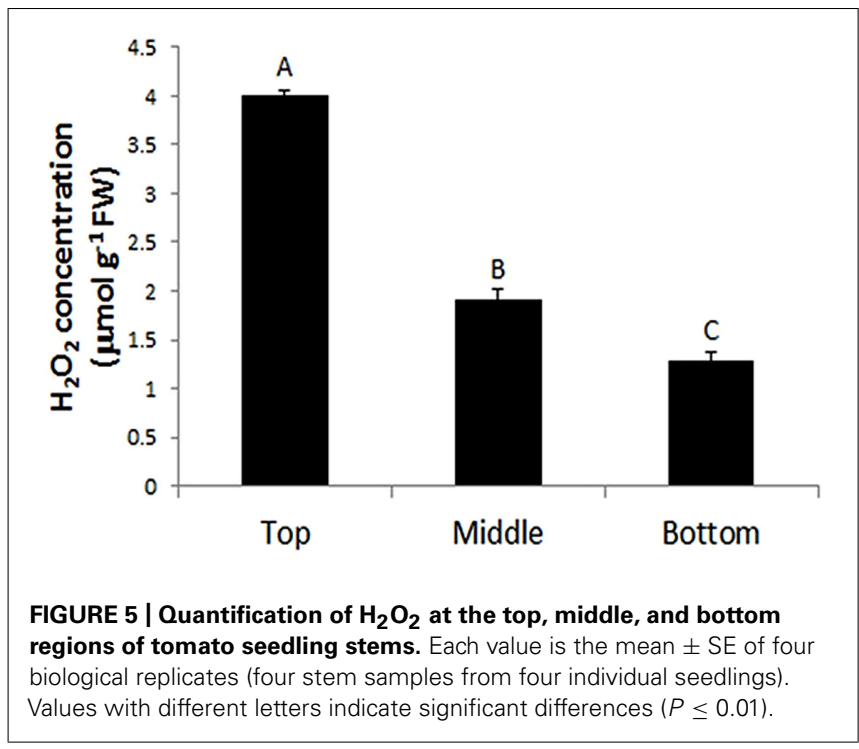




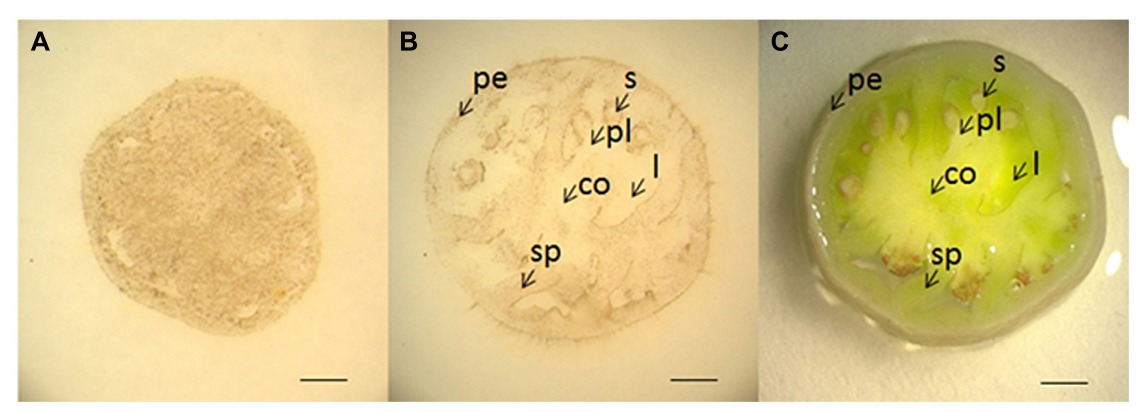

FIGURE 6 | Localization of $\mathrm{H}_{2} \mathrm{O}_{2}$ in young tomato fruits using DAB-mediated tissue printing. Cross sections (1 $\mathrm{mm}$ thick) were cut transversely from the middle of tomato fruits at 5 (A) and 10 (B) DAF. (C)
Shows the corresponding picture of fruit section used in (B). co, columella; I, locule; pe, pericarp; pl, placenta; s, seed; sp, septum. Scale bars in (A-C) represent 1,2 , and $2 \mathrm{~mm}$, respectively. the localized signal strength in sections (Figure 4) provides further evidence that our DAB-mediated tissue printing is reliable and can semi-quantitatively reflect $\mathrm{H}_{2} \mathrm{O}_{2}$ distribution in plant organs.

To test if the method is applicable to other large organs, we examined $\mathrm{H}_{2} \mathrm{O}_{2}$ localization in tomato fruits at 5 and 10 DAF using DAB-mediated tissue printing. At $5 \mathrm{DAF}, \mathrm{H}_{2} \mathrm{O}_{2}$ was detected abundantly and evenly throughout the section (Figure 6A). However, by 10 DAF, $\mathrm{H}_{2} \mathrm{O}_{2}$ appeared to be more tissue-specific, in which $\mathrm{H}_{2} \mathrm{O}_{2}$ was abundant in pericarp, seed, and septum, and no $\mathrm{H}_{2} \mathrm{O}_{2}$ signal was found in columella, locule, and placenta regions (Figures 6B,C). These results suggest that $\mathrm{H}_{2} \mathrm{O}_{2}$ distribution is also highly regulated during the development of tomato fruits.

It has been reported that ROS promotes cell division through accelerating auxin-mediated cell cycle entry in alfalfa (Medicago sativa; Fehér et al., 2008). ROS is also involved in the establishment and maintenance of root apical dominance in Arabidopsis (De Tullio et al., 2010) and formation of lateral roots in rice (Chen et al., 2013). Therefore, the higher level of $\mathrm{H}_{2} \mathrm{O}_{2}$ in the top of the stem (Figures 4A and 5) and younger fruit (5 DAF; Figure 6A) might be indicative of high activities of cell division in these organs.

In conclusion, localization of $\mathrm{H}_{2} \mathrm{O}_{2}$ within large plant organs (e.g., stem and large fruit) other than thin and flat leaves is technically challenging. In this paper, we report the development of a DAB-mediated tissue printing method to localize $\mathrm{H}_{2} \mathrm{O}_{2}$ in tomato stem and fruit. The rapidity of our protocol (within $15 \mathrm{~s}$ ) can effectively avoid the interference of wound-induced $\mathrm{H}_{2} \mathrm{O}_{2}$. This represents a major advantage over the protocol reported by Thordal-Christensen et al. (1997) where leaf stripes were incubated in DAB containing solutions for $8 \mathrm{~h}$, inevitably leading to wound-induced $\mathrm{H}_{2} \mathrm{O}_{2}$ (Miller et al., 2009; Swanson et al., 2011). Another advantage is that the signal strength of $\mathrm{H}_{2} \mathrm{O}_{2}$ from our tissue printing was stably maintained for at least $1 \mathrm{~h}$ after tissue printing with no or little background developed. Furthermore, owing to high consistency between the signal intensity of localized $\mathrm{H}_{2} \mathrm{O}_{2}$ and its quantified concentration, the protocol can also be used to semi-quantitatively reflect the $\mathrm{H}_{2} \mathrm{O}_{2}$ distribution in plant organs. Thus, our protocol is a simple way to specifically, rapidly, and reliably localize $\mathrm{H}_{2} \mathrm{O}_{2}$ in large plant organs.

\section{ACKNOWLEDGMENTS}

The work was funded, in part, from The University of Newcastle, Australia, as a support to The Australia-China Research Centre for Crop Improvement. Yong-Hua Liu is a recipient of a postgraduate research scholarship from The University of Newcastle. We also thank Joseph Enright for his excellent work in plants cultivation.

\section{REFERENCES}

Apel, K., and Hirt, H. (2004). Reactive oxygen species: metabolism, oxidative stress, and signal transduction. Annu. Rev. Plant Biol. 55, 373-399. doi: 10.1146/annurev.arplant.55.031903.141701

Bestwick, C. S., Brown, I. R., Bennett, M. H., and Mansfield, J. W. (1997). Localization of hydrogen peroxide accumulation during the hypersensitive reaction of lettuce cells to Pseudomonas syringae pv phaseolicola. Plant Cell 9, 209-221. doi: 10.1105/tpc.9.2.209

Bienert, G. P., Møller, A. L. B., Kristiansen, K. A., Schulz, A., Møller, I. M., Schjoerring, J. K., et al. (2007). Specific aquaporins facilitate the diffusion of hydrogen peroxide across membranes. J. Biol. Chem. 282, 1183-1192. doi: 10.1074/jbc.M603761200

Cheeseman, J. M. (2006). Hydrogen peroxide concentrations in leaves under natural conditions. J. Exp. Bot. 57, 2435-2444. doi: 10.1093/jxb/erl004

Chen, Y. H., Chao, Y. Y., Hsu, Y. Y., and Kao, C. H. (2013). Heme oxygenase is involved in $\mathrm{H}_{2} \mathrm{O}_{2}$-induced lateral root formation in apocynin-treated rice. Plant Cell Rep. 32, 219-226. doi: 10.1007/s00299-012-1356-3

Choudhury, S., Panda, P., Sahoo, L., and Panda, S. K. (2013). Reactive oxygen species signaling in plants under abiotic stress. Plant Signal. Behav. 8, e23681. doi: $10.4161 /$ psb. 23681

De Tullio, M. C., Jiang, K., and Feldman, L. J. (2010). Redox regulation of root apical meristem organization: connecting root development to its environment. Plant Physiol. Bioch. 48, 328-336. doi: 10.1016/j.plaphy.2009.11.005

Essmann, J., Schmitz-Thom, I., Schön, H., Sonnewald, S., Weis, E., and Scharte, J. (2008). RNA interference-mediated repression of cell wall invertase impairs defense in source leaves of tobacco. Plant Physiol. 147, 1288-1299. doi: 10.1104/pp.108.121418

Fehér, A., Ötvös, K., Pasternak, T. P., and Szandtner, A. P. (2008). The involvement of reactive oxygen species (ROS) in the cell cycle activation (G0-to-G1 transition) of plant cells. Plant Signal. Behav. 3, 823-826. doi: 10.4161/psb.3.10.5908

Macarisin, D., Cohen, L., Eick, A., Rafael, G., Belausov, E., Wisniewski, M., et al. (2007). Penicillium digitatum suppresses production of hydrogen peroxide in host tissue during infection of citrus fruit. Phytopathology 97, 1491-1500. doi: 10.1094/PHYTO-97-11-1491

Miller, G., Schlauch, K., Tam, R., Cortes, D., Torres, M. A., Shulaev, V., et al. (2009). The plant NADPH oxidase RBOHD mediates rapid systemic signaling in response to diverse stimuli. Sci. Signal. 2, ra45. doi: 10.1126/scisignal.2000448

Nagasawa, N., Hibara, K. I., Heppard, E. P., Vander Velden, K. A., Luck, S., Beatty, M., et al. (2013). GIANT EMBRYO encodes CYP78A13, required for proper size balance between embryo and endosperm in rice. Plant J. 75, 592-605. doi: $10.1111 /$ tpj.12223 
Neves, C., Sá, M. C., and Amâncio, S. (1998). Histochemical detection of $\mathrm{H}_{2} \mathrm{O}_{2}$ by tissue printing as a precocious marker of rhizogenesis in grapevine. Plant Physiol. Bioch. 36, 817-824. doi: 10.1016/S0981-9428(99)80019-9

Olson, P., and Varner, J. (1993). Hydrogen peroxide and lignification. Plant J. 4, 887-892. doi: 10.1046/j.1365-313X.1993.04050887.x

Petrov, V. D., and Van Breusegem, F. (2012). Hydrogen peroxide-a central hub for information flow in plant cells. AoB plants pls014. doi: 10.1093/aobpla/pls014

Przymusiński, R., Rucińska-Sobkowiak, R., Ilska, B., and Gwóźdź, E. A. (2007) Organospecific responses of lupin seedlings to lead localization of hydrogen peroxide and peroxidase activity. Acta Physiol. Plant 29, 411-416. doi: 10.1007/s11738-007-0049-y

Queval, G., Hager, J., Gakière, B., and Noctor, G. (2008). Why are literature data for $\mathrm{H}_{2} \mathrm{O}_{2}$ contents so variable? A discussion of potential difficulties in the quantitative assay of leaf extracts. J. Exp. Bot. 59, 135-146. doi: 10.1093/jxb/erm193

Razem, F. A. (2008). An overview of hydrogen peroxide production and cellular determination in plants. Hebron University Res. J. 3, 84-96.

Reth, M. (2002). Hydrogen peroxide as second messenger in lymphocyte activation. Nat. Immunol. 3, 1129-1134. doi: 10.1038/ni1202-1129

Romero-Puertas, M. C., Rodríguez-serrano, M., Corpas, F. J., Gómez, M., Del Río, L. A., and Sandalio, L. M. (2004). Cadmium-induced subcellular accumulation of $\mathrm{O} 2$ middot- and $\mathrm{H}_{2} \mathrm{O}_{2}$ in pea leaves. Plant Cell Environ. 27, 1122-1134. doi: 10.1111/j.1365-3040.2004.01217.x

Salzer, P., Corbière, H., and Boller, T. (1999). Hydrogen peroxide accumulation in Medicago truncatula roots colonized by the arbuscular mycorrhiza-forming fungus Glomus intraradices. Planta 208, 319-325. doi: 10.1007/s004250050565

Schopfer, P. (1994). Histochemical demonstration and localization of $\mathrm{H}_{2} \mathrm{O}_{2}$ in organs of higher plants by tissue printing on nitrocellulose paper. Plant Physiol. 104, 1269-1275.

Spruce, J., Mayer, A. M., and Osborne, D. J. (1987). A simple histochemical method for locating enzymes in plant tissue using nitrocellulose blotting. Phytochemistry 26, 2901-2903. doi: 10.1016/S0031-9422(00)84559-8

Suzuki, N., Koussevitzky, S., Mittler, R., and Miller, G. (2012). ROS and redox signalling in the response of plants to abiotic stress. Plant Cell Environ. 35, 259 270. doi: 10.1111/j.1365-3040.2011.02336.x
Swanson, S. J., Choi, W. G., Chanoca, A., and Gilroy, S. (2011). In vivo imaging of $\mathrm{Ca} 2+, \mathrm{pH}$, and reactive oxygen species using fluorescent probes in plants. Annu. Rev. Plant Biol. 62, 273-297. doi: 10.1146/annurev-arplant-042110103832

Thordal-Christensen, H., Zhang, Z. G., Wei, Y. D., and Collinge, D. B. (1997). Subcellular localization of $\mathrm{H}_{2} \mathrm{O}_{2}$ in plants. $\mathrm{H}_{2} \mathrm{O}_{2}$ accumulation in papillae and hypersensitive response during the barley-powdery mildew interaction. Plant J. 11, 1187-1194. doi: 10.1046/j.1365-313X.1997. 11061187.x

Van Breusegem, F., Bailey-Serres, J., and Mittler, R. (2008). Unraveling the tapestry of networks involving reactive oxygen species in plants. Plant Physiol. 147, 978-984. doi: 10.1104/pp.108.122325

Veljovic-Jovanovic, S., Noctor, G., and Foyer, C. H. (2002). Are leaf hydrogen peroxide concentrations commonly overestimated? The potential influence of artefactual interference by tissue phenols and ascorbate. Plant Physiol. Biochem. 40, 501-507. doi: 10.1016/S0981-9428(02)01417-1

Conflict of Interest Statement: The authors declare that the research was conducted in the absence of any commercial or financial relationships that could be construed as a potential conflict of interest.

Received: 10 October 2014; accepted: 06 December 2014; published online: 22 December 2014.

Citation: Liu Y-H, Offler CE and Ruan Y-L (2014) A simple, rapid, and reliable protocol to localize hydrogen peroxide in large plant organs by DAB-mediated tissue printing. Front. Plant Sci. 5:745. doi: 10.3389/fpls.2014.00745

This article was submitted to Plant Physiology, a section of the journal Frontiers in Plant Science.

Copyright (C) 2014 Liu, Offler and Ruan. This is an open-access article distributed under the terms of the Creative Commons Attribution License (CC BY). The use, distribution or reproduction in other forums is permitted, provided the original author(s) or licensor are credited and that the original publication in this journal is cited, in accordance with accepted academic practice. No use, distribution or reproduction is permitted which does not comply with these terms. 